\title{
The Development of a Trilingual Dictionary for Elementary Students
}

\author{
Ni Luh Putu Sri Adnyani ${ }^{1}$ Ni Made Rai Wisudariani ${ }^{1, *}$ I Nyoman Pasek Hadisaputra ${ }^{1}$ \\ Ni Komang Arie Suwastini ${ }^{1}$ Putu Wiraningsih ${ }^{1}$
}

\author{
${ }^{1}$ English Language Education Study Program, Universitas Pendidikan Ganesha, Singaraja, Indonesia \\ *Corresponding author.Email: rai.wisudariani@undiksha.ac.id
}

\begin{abstract}
Elementary schools in Bali introduce a minimum of three languages, including Balinese as a local language, Indonesian as the national language, and English as a foreign language to students. However, the presence of a dictionary that is focused in assisting students in mastering the three languages is very limited. Thus, this study was aimed at; 1) analyzing the scope of vocabularies that must be learned by elementary school students, 2) developing a trilingual Balinese-Indonesian-English dictionary for elementary school students. Applying research and development design, the data were collected through observation, interviews and document studies. The results revealed that there were 18 major themes of vocabularies that should be learned in Balinese, Indonesian, and English. Contextual selection of themes and vocabulary accompanied by illustrations provides a better understanding in acquiring the new vocabularies. Besides, the efforts to preserve local culture and maintain self-identity in globalization era can also be achieved.
\end{abstract}

Keywords: dictionary, elementary students, trilingual

\section{INTRODUCTION}

Most elementary schools in Bali teach a minimum of three languages, including Balinese as a local language, Indonesian as the national language, and English as a foreign language. This is in line with the education curriculum in Indonesia where three languages are taught, namely a local language, Indonesian as the national language, and English as a foreign language. Balinese as one of the local languages becomes a Balinese community entity that is part of the cultural index [1]. In accordance with the 2013 Curriculum, the Balinese language belongs to a compulsory subject that is incorporated in the type of local content [2].

Indonesian as the national language has a function as a symbol of national pride, national identity, a uniting tool for different ethnicities, as well as a connecting tool between cultures and between regions that must be mastered by all Indonesian citizens [3]. English as lingua franca serves as a bridge between nations so that by learning English, students are expected to be able to become a global community. These three languages are taught starting from primary education as an initial introduction to the language used in everyday life before moving on to the next level of formal education at the secondary and higher education levels [4], [5].

Supplementary learning materials were found to be effectively enhance the teaching learning process [6], [7], [8], [9]. The presence of a visual dictionary as a supplementary learning material is essential for Indonesian students who study multiple languages [6]. The use of a dictionary associated with the illustrations can increase the ability of students in gaining some new words by allowing them to visualize the objects of the referenced words. It can also assist teachers convey the information more effectively and shorten the explanations [10]. As the result, students can develop their memory to grasp new vocabularies thus the learning process of a new language would be easier.

Although the use of dictionary brings beneficial effect for students in acquiring new languages, the result of the studies along with the interviews with language teachers in elementary schools in Bali revealed that the development of a three-language (trilingual) dictionary with illustrations that is focused in assisting students in mastering the three languages is very limited [11], [12]. The common dictionary that is widely used is the 
bilingual dictionary [13], [14], [15], [16]. The absence of a trilingual dictionary for each grade level in elementary school is a problem that needs to be solved. Therefore, this study aimed to; 1) analyze the scope of vocabularies that elementary school students must learn in Balinese, Indonesian, and English, as well as 2) develop a trilingual Balinese-Indonesian-English dictionary for elementary school students in Bali. This research was worth to be conducted since this might help teachers in introducing new vocabularies, to be mastered by the students. Furthermore, students can improve their language skills in both local, national, and foreign languages.

\section{LITERATURE REVIEW}

\subsection{Learning Balinese as a Local Language}

Indonesia is a country with a diverse range of local languages spoken in each region. Besides serving as a medium of communication, local languages in Indonesia also act as a cultural support system for various ethnic groups living the country [17]. One of the regulations stated that local languages can be used as the language of instruction in the early stages of education [18]. In addition, Balinese as one of the local languages belongs to one of the local content subjects that must be taught at national standard schools.

The purpose of the Balinese language is to serve as a communication tool so that students can use it appropriately and accurately when engaging in the family and community. A local wisdom value of respect exists in the Balinese language among the speakers, which includes the one speaking, the person being spoken to, and the person who is being talked about. Learning Balinese language is also a way to establish identity and instill a filter against the influence of other foreign cultures [19]. Through learning Balinese, it is not merely aimed to enable students to communicate but also preserve cultural values. In other words, Balinese cultural values will be instilled, and these values are ready to help the country develop a strong cultural identity, and which, in the end, can help Indonesia filters foreign cultures.

\subsection{Learning Indonesian as a National Language}

As a multicultural and multilingual country, Indonesia is well-known around the world. As the result, people may have difficulty in communicating and understanding one another when they are speaking with people from different regions. Therefore, Indonesian language occupies a critical position as a means of communication between cultures and regions. Indonesian is the official language of the country and serves as a uniting language for the entire country [3], [4].
Indonesian language is one of the most significant components of Indonesian culture that students should learn in schools. This language is taught initially in elementary school since it is expected that students would be able to learn, understand, and apply the language skills such as reading, listening, writing, and speaking. It is also expected that students would be able to communicate in Indonesian properly and correctly, both orally and in writing, as well as fostering an appreciation of the work of Indonesian human literature [20], [21]. Thus, learning Indonesian language is expected to help students get to know themselves, their culture, and the cultures of others, express ideas and feelings, participate in communities that use the language, and discover and use their analytical and imaginative abilities. This is in accordance with Permendiknas No. 22 of 2006 which stated that language has a critical role in the intellectual, social, and emotional development of students, and it is a predictor of academic success in all disciplines of study.

\subsection{Learning English as a Foreign Language}

In addition to learning Balinese and Indonesian, English is also taught at the formal education level as a foreign language. English has been widely studied in Indonesia since the 1960s and officially became the first foreign language taught in schools in accordance with the Decree of the Minister of Education and Culture No. 096/1967 dated December 12, 1967. Because of its status as an international language, or what is commonly referred to as a lingua franca, English is chosen to be taught alongside other foreign languages. According to [3], a foreign language as a lingua franca has a position or function as a connecting tool between nations as well as a means of utilizing modern science and technology.

In accordance with the implementation of the 2013 Curriculum in Indonesia, English has been taught in elementary schools as a local content subject which is taught once a week. Through learning English at school, students will be able to apply the language in everyday life [22]. Furthermore, one of the goals of English language instruction in Indonesian schools is to enable Indonesian students to become more competitive on the worldwide level [23].

\subsection{The Importance of Dictionaries in Language Learning}

A dictionary is a media or a supporting tool consisting of a list of words arranged alphabetically with meaning and pronunciation [24], [25]. Dictionaries have an important role to help students in recognizing new vocabularies [26]. If students learn how to correctly use a dictionary, the dictionary can prove to be a very useful resource for them such as determining the specific meaning of an unfamiliar word. A dictionary also provides information towards the pronunciation of new words, the frequency of use and the appropriate usage of 
unfamiliar words. The use of a dictionary in language learning can help a student to be more independent. It allows students to identify the suitable interpretations of unknown terms in sentences without relying on the explanations of their teachers [27], [28], [29]. Thus, the use of a dictionary will be beneficial for students in finding the meaning that is most suited for a given context.

\section{METHODS}

\subsection{Research Design}

The design of this research was RnD (Research and Development). This research was conducted through two stages. An overview of each stage can be seen in Figure 1. This research was conducted in two stages as follows: 1. The first stage consisted of reviews of the competencies that must be achieved by grade one elementary school students in Bali in learning Balinese, Indonesia, and English. An analysis was also carried out at this stage in order to determine which vocabulary would be included in the trilingual dictionary. Following an analysis of curricula and syllabuses, discussion with language learning specialists, and a review of relevant literature, the materials were developed into a trilingual dictionary. 2. The second stage consisted of compiling and developing an illustrated Balinese-Indonesia-English trilingual dictionary for grade one elementary school students.

\subsection{Source of Data}

The source of data of this study consisted of two different sources. First, the literature related to Balinese, Indonesia, and English subjects, such as curriculum, syllabus, teaching materials that provide information about competencies that must be mastered by grade one elementary school students. Second, the experts who master their respective fields of language and who contributed input into the content of the Balinese, Indonesian, and English trilingual dictionary.

\subsection{Data Collection Procedure}

During the data collection process, the researchers conducted a review of related literature, which included curriculum, syllabus, and teaching materials that were implemented in the teaching in order to decide the vocabularies that should be learned by the students. After that, a note was created to list the vocabularies that corresponded to the learning objectives provided in the syllabus, as well as the instructional materials. The resulting vocabulary list was then illustrated in the form of some pictures. After obtaining the final word list arrangement, the word list was then recorded through the Lexique Pro software which can be downloaded for free from the http://www.lexiquepro.com/ page. The list of words that have been listed was then transferred into MS Word which can be printed in the form of a dictionary.

\subsection{Data Analysis Technique}

In this study, the qualitative data were analyzed descriptively. The first step was identifying and analyzing the vocabulary that must be mastered by grade one elementary school students in learning Balinese, Indonesian, and English. The data were collected through observation, interviews and document studies.

In developing a Balinese-Indonesia-English trilingual dictionary, the data were validated through a Focus Group Discussion (FGD). The content was then validated by using the Gregory formula shown in Table 1.

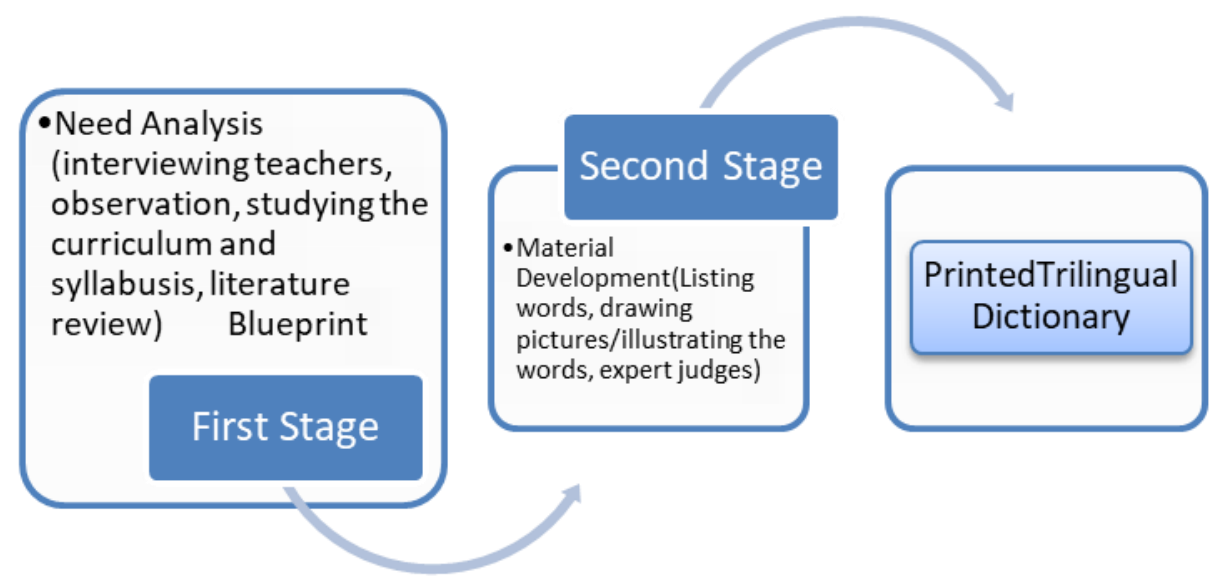

Figure 1. Research Design 
Table 1 Gregory formula

\begin{tabular}{|c|c|c|c|}
\hline \multicolumn{2}{|c|}{} & \multicolumn{2}{c|}{ Expert 1 } \\
\cline { 3 - 4 } \multicolumn{2}{|c|}{} & Relevant & Irrelevant \\
\hline \multirow{2}{*}{ Expert 2 } & Relevant & A (- $)$ & B (- +) \\
\cline { 2 - 4 } & Irrelevant & C (+-) & D (++) \\
\hline
\end{tabular}

Content Validity $=\frac{\mathrm{D}}{\mathrm{A}+\mathrm{B}+\mathrm{C}+\mathrm{D}}$.

Notes:

A: expert 1 and 2 disagree

B: expert 1 disagree, expert 2 agree

C: expert 1 agree, expert 2 disagree

D: expert 1 and 2 are agree

\section{FINDINGS AND DISCUSSION}

\subsection{The Scope of Vocabulary that Must be Learned by Elementary School Students in Balinese-Indonesia-English}

After conducting document studies, observations, and interviews, the design of a trilingual dictionary was obtained. In this trilingual dictionary, the scope of vocabulary that elementary school students must learn was divided into 18 major themes including; 1) numbers, 2) alphabet, 3) colors, 4) shapes, 5) family, 6) parts of body, 7) fruits, 8) animals, 9) family, 10) favorite foods and drinks, 11) things in the bag, 12) school uniforms, 13) objects in the classroom, 14) school buildings, 15) objects in the house 16) parts of the house, 17) in the kitchen, 18) objects in the bathroom. Some of the vocabulary lists can be seen in Table 2. Table 2 shows some list of vocabularies contained in this trilingual dictionary that should be learned by elementary school students. In developing this trilingual dictionary, the selection of themes and vocabulary take into account the vocabulary that students usually use in their daily lives, such as numbers, body parts, toys, animals, and greetings. This is because the trilingual dictionary is intended for grade one elementary school students who are still in a phase which according to [30] is called as the Concrete Operational Stage. Concrete Operational Stage is a phase of child development where at this phase, children are able to think rationally and logically, but their abilities are still limited to concrete objects. This phase is through by children at the age of seven to eleven years. By choosing vocabulary that is close to students' daily lives and combined with some illustrations, they can easily understand and remember the information conveyed.

In addition to make it easier for students to learn Balinese, Indonesian, and English, the selection of contextual vocabulary indirectly preserves the cultures of the language being learned, for example the number theme in Balinese. In this theme, students were taught to recognize the numbers one to one hundred in Balinese. There are several numbers that are emphasized because they have special naming such as salikur stands for 'twenty-one', selae stands for 'twenty-five', seket stands for 'fifty', ulung dasa stands for 'eighty', and satus stands for 'one hundred'. In addition, on the theme of salam 'greetings', students are taught to give greetings in three languages. By learning the expression such as suksma 'thank you' and tulung 'please' in three languages, students will learn to communicate and behave politely in social life.

This is in line with the purpose of the Governor of Bali's decree on teaching Balinese No. 20 of 2013 where teaching Balinese through formal education at the elementary school level is an important means of educating children with good manners in society. Thus, the efforts to preserve culture in Bali and maintain selfidentity in social life in the era of globalization can be carried out [31]. Balinese, Indonesia, and English are three languages that students learn at the elementary school level. Along with 2013 Curriculum, Indonesian language is a language that must be studied as a national language. This is in accordance with [32] who states that Indonesian language is a compulsory subject that must be taught at all levels of education, especially in elementary schools as a unifying language of the nation

Table 2 List of words in trilingual dictionary

\begin{tabular}{|c|c|c|c|}
\hline Theme & \multicolumn{3}{|c|}{ Vocabulary } \\
\hline \multirow{6}{*}{$\begin{array}{l}\text { Angka/Angk } \\
\text { a/ Numbers }\end{array}$} & Bali & Indonesian & Inggris \\
\hline & salikur & $\begin{array}{l}\text { dua puluh } \\
\text { satu }\end{array}$ & twenty one \\
\hline & selae & $\begin{array}{l}\text { dua puluh } \\
\text { lima }\end{array}$ & twenty five \\
\hline & seket & lima puluh & fifty \\
\hline & $\begin{array}{l}\text { ulung } \\
\text { dasa }\end{array}$ & $\begin{array}{l}\text { delapan } \\
\text { puluh }\end{array}$ & eighty \\
\hline & satus & seratus & one hundred \\
\hline \multirow{5}{*}{$\begin{array}{c}\text { Perangganin } \\
\text { g Angga/ } \\
\text { Anggota } \\
\text { Tubuh/ Parts } \\
\text { of Body }\end{array}$} & sirah & kepala & head \\
\hline & baong & leher & neck \\
\hline & lime & tangan & hand \\
\hline & tangkah & dada & chest/bust \\
\hline & basang & perut & stomach \\
\hline \multirow{5}{*}{$\begin{array}{l}\text { Plalianan/ } \\
\text { Mainan/ } \\
\text { Toys }\end{array}$} & $\begin{array}{l}\text { montor- } \\
\text { montoran }\end{array}$ & $\begin{array}{c}\text { mobil- } \\
\text { mobilan }\end{array}$ & toy car \\
\hline & trek & truk & truck \\
\hline & layangan & $\begin{array}{l}\text { layang- } \\
\text { layang }\end{array}$ & kite \\
\hline & $\begin{array}{c}\text { kembung } \\
\text { an }\end{array}$ & balon & balloon \\
\hline & togog & boneka & doll \\
\hline \multirow{5}{*}{$\begin{array}{l}\text { Buron/ } \\
\text { Hewan/ } \\
\text { Animals }\end{array}$} & meong & kucing & cat \\
\hline & cicing & anjing & dog \\
\hline & siap & ayam & chicken \\
\hline & celeng & babi & pig \\
\hline & sampi & sapi & cow \\
\hline \multirow{2}{*}{$\begin{array}{c}\text { Penganjali/ } \\
\text { Salam/ } \\
\text { Greetings }\end{array}$} & suksma & $\begin{array}{c}\text { terima } \\
\text { kasih }\end{array}$ & $\begin{array}{l}\text { thanks/ } \\
\text { thank you }\end{array}$ \\
\hline & tulung & tolong & help \\
\hline
\end{tabular}


In other words, being able to speak in Indonesian language is not merely about communicating, but also understanding the meaning and using it properly according to the culture and society of the language users [32], [33]

Elementary schools in Bali also teach Balinese and English as the local content. Balinese as a local language functioned as a means of communication and cultural support for Balinese local communities in Indonesia [3], [17]. In other words, the local languages that emerged in Indonesia serves a variety of tasks, including functioning as a marker of regional identity, a link between communities, a method of promoting culture, and a medium for the promotion of Indonesian literature. English is chosen to be taught among other foreign languages because of its position as an international language or what is often referred to as a lingua franca. A foreign language as a lingua franca functioned as a connecting tool between nations as well as a means of utilizing modern science and technology [3]. Furthermore, English is important to be taught in schools so that students are able to apply the language in everyday life [22]. With the development of the trilingual dictionary, this learning media has covered all the languages being taught so that there is continuity between one language and another. Therefore, for students who study multiple languages, the development of a trilingual dictionary is beneficial in supporting the language learning process.

\subsection{Developing the Illustrated Balinese- Indonesian-English Trilingual Dictionary}

In developing the trilingual Balinese-IndonesianEnglish Illustrated Dictionary, several steps were carried out as follows: 1). The first stage was reviewing the literature including the curriculum, syllabus and teaching materials used. It was aimed to identify and analyze the vocabulary that must be learned by grade 1 elementary school students in learning Balinese, Indonesia, and English. Data were collected through observation, interviews and document studies. The data collected were analyzed descriptively. 2). After conducting a literature review, observation, interview, and document study, a list of vocabularies contained in the syllabus and teaching materials was compiled using an instrument in the form of a note sheet. The listed vocabularies comprised 18 major themes that are relevant to students' everyday situations. 3). The listed vocabulary of the BalineseIndonesian-English trilingual dictionary was then validated through a Focus Group Discussion (FGD). The listed vocabularies were then validated in terms of content using the Gregory formula. The result of Gregory's formula shows an average of 0.79 which means it is highly valid. Thus, the listed vocabularies can be included in the dictionary. 4). The list of vocabularies that have been validated was then developed into a design of trilingual dictionary. A series of pictures were used to illustrate the words listed. After obtaining the illustrations and the composition of the final word list, the word list was then recorded through the Lexique Pro software which can be downloaded for free from the http://www.lexiquepro.com/ page. The list of words that have been listed then was transferred into MS Word which can be printed in the form of a dictionary. The final product of this trilingual dictionary consists of the themes, the words in Balinese, Indonesia, and English, the example of sentence for each word, and the illustrations as can be seen in Figure 2 .

Indonesian students who live in the multilingual country were often challenged in learning various languages. The Dictionary helps students to look up the meaning of foreign words they encounter, how to use and pronounce them [24], [25]. Dictionaries have an effective contribution to language learning that has been specialized and adapted to the needs of students [6]. Notion classifies the use of dictionaries into productive and receptive use [34]. Productive use of dictionaries is also referred to as encoding, namely converting ideas into language. This involves choosing the right words to express the message. Meanwhile, receptive use of dictionaries mostly involves searching for the meaning of a word that has been encountered while reading or listening. In addition, [34] stated that dictionaries can help learners in three ways, namely (1) providing assistance to students in comprehending the new terms found when reading texts and listening to information; (2) assisting students in finding the words they require for oral and written communication; and (3) helping students to expand their vocabulary.

A dictionary serves as practical and theoretical functions [35]. In terms of practical functions, the dictionary serves to find out word pronunciation and word meaning. Meanwhile, from a theoretical point of view, the dictionary has a function to integrate cultural concepts, namely vocabulary that is often used in a community group. Dictionaries provide linguistic information and cultural information, especially when learning is not accompanied by teachers so that students are responsible for their own learning [36].

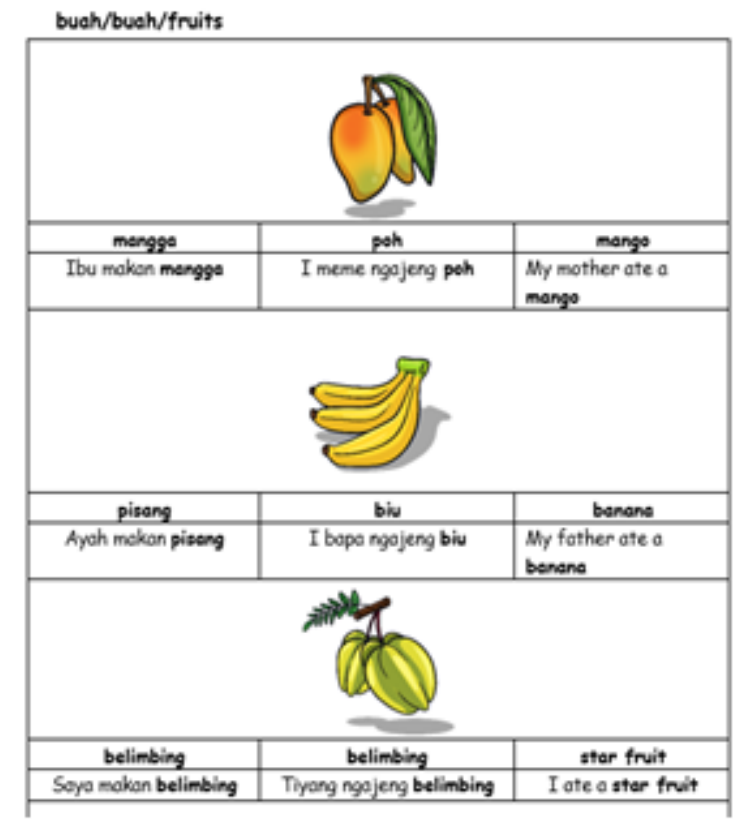

Figure 2 The preview of the trilingual dictionary developed 
Therefore, when students know how to use it effectively, independent learning activities can be realized.

\section{CONCLUSION}

Based on the results of the research and development study of Balinese-Indonesia-English trilingual dictionary for elementary students, it can be concluded that the vocabularies that must be learned by the elementary students was listed into 18 major themes. Several stages were completed starting from reviewing the literature, listing the vocabularies, validating content, inputting the listed words through the Lexique Pro software, templating, and printing. The use of the dictionary as a learning media is beneficial for students. The benefits include being able to determine the meaning of new words they meet, as well as how to use and pronounce them properly. The use of a trilingual dictionary as a supplementary learning resource has covered all of the languages that students are required to learn. As a result, there will be a sense of continuity between one language and another. Contextual selection of themes and vocabulary accompanied by illustrations help students understanding and remember the information presented. Using this trilingual dictionary, the attempts to conserve culture and sustain self-identity in community life can be also carried out in this age of globalization.

\section{ACKNOWLEDGMENT}

This study was funded by Universitas Pendidikan Ganesha under the grant DIPA BLU number 526/UN48.16/LT/2021

\section{REFERENCES}

[1] I. M. Giri, "Pelestarian bahasa, aksara, dan sastra Bali melalui pengoptimalan tripusat pendidikan," Purwadita J. Agama dan Budaya, vol. 1, no. 1, 2018, [Online]. Available: http://jurnal.stahnmpukuturan.ac.id/index.php/Pu rwadita/article/view/6.

[2] Pemprov Bali, "Peraturan Gubernur Bali Nomor 20 Tahun 2013 tentang Bahasa, Aksara dan Sastra Daerah Bali pada Pendidikan Dasar dan Menengah," 2013.

[3] H. Alwi and H. Sugono, "Politik bahasa: Rumusan seminar politik bahasa," 2003.

[4] J. S. Badudu, Cakrawala Bahasa Indonesia II, 1st ed. Jakarta: Gramedia Pustaka Utama, 1992.

[5] U. Khair, "Pembelajaran bahasa Indonesia dan sastra (BASASTRA)," AR-RIAYAH J. Pendidik. Dasar, vol. 2, no. 1, pp. 81-98, 2018, [Online]. Available: http://dx.doi.org/10.29240/jpd.v2i1.261.

[6] G. K. Aleeva and G. R. Safiullina, "Using dictionaries in teaching English as a foreign language," Int. J. Environ. Sci. Educ., vol. 11, no. 9, pp. 27-34, 2016, [Online]. Available: https://files.eric.ed.gov/fulltext/EJ1114632.pdf.

[7] A. R. Dodd et al., "The use of supplementary materials in English foreign language classes in Ecuadorian secondary schools," English Lang. Teach., vol. 8, no. 9, pp. 187-195, 2015, [Online]. Available: http://dx.doi.org/10.5539/elt.v8n9p187.

[8] Z. Maden and E. N. Ozaslan, "The use of power point presentations at in the department of foreign language education at Middle East Technical University," Middle East. African J. Educ. Res., vol. 2, pp. 38-45, 2013, [Online]. Available:

http://www.majersite.org/issue2/ozaslanandmad en.pdf.

[9] U. Umar, "Media pendidikan: Peran dan fungsinya dalam pembelajaran," J. Tarb., vol. 11, no. 1, pp. 131-144, 2014, [Online]. Available: https://ejournal.metrouniv.ac.id/index.php/tarbawiyah/art icle/view/364

[10] M. Subana and Sunarti, Strategi belajar mengajar bahasa Indonesia, 3rd ed. Bandung: Pustaka Setia, 2011.

[11] N. K. P. Adnyani, "Developing a multilingual thematic picture dictionary for assisting sixth grade elementary school students' literacy," $J$ Pendidik. Bhs. Ingg. Undiksha, vol. 9, no. 1, 2021, [Online]. Available: http://dx.doi.org/10.23887/jpbi.v8i2.27507.

[12] N. M. Suniyasih, N. M. Ratminingsih, and I. G Budasi, "Development of multilingual thematic picture dictionary: A support for literacy," $J$ Pendidik. dan Pengajaran, vol. 53, no. 3, pp. 236-243, 2020, [Online]. Available: http://dx.doi.org/10.23887/jpp.v53i3.27508.

[13] M. A. R. Hakim, M. J. Z. Abidin, and A. Bahari, "Dictionary use to increase students' vocabulary mastery: Electronic dictionary or printed one,' 2020, [Online]. Available: http://dx.doi.org/10.5220/0008215001500159.

[14] F. M. Ivone, "Teaching English as a foreign language in Indonesia: The urge to improve classroom vocabulary instruction," TEFLIN J., vol. 16, no. 2, pp. 195-208, 2005, [Online]. Available:

http://dx.doi.org/10.15639/teflinjournal.v16i2/19 5-208.

[15] A. R. Rahim and A. Thaba, "Development illustrated dictionary with local culture to support cultural literation on elementary school," Rev. Int. Geogr. Educ. Online, vol. 11, no. 5, pp. 2812-2828, 2021, [Online]. Available: https://rigeo.org/submit-a- 
menuscript/index.php/submission/article/view/1 076 .

[16] N. Setiowati, "The effectiveness of pictured bilingual dicitonary compared to non-pictured bilingual dictionary to improve the vocabulary mastery of elementary school students," ELT Forum J. English Lang. Teach., vol. 2, no. 2, 2013, [Online] Available: https://doi.org/10.15294/elt.v2i2.2417.

[17] I. N. Suandi, I. B. Putrayasa, and I. W. Wisnu, "Penyusunan kamus serapan dalam bahasa Bali," J. Ilmu Sos. dan Hum., vol. 4, no. 2, pp. 675-690, 2015, [Online]. Available: http://dx.doi.org/10.23887/jishundiksha.v4i2.6387.

[18] Undang-Undang No 20 Tahun 2003 tentang Sistem Pendidikan Nasional. Indonesia, 2003.

[19] A. A. Semadi, "Pendidikan dan pengajaran bahasa Bali dengan pendekatan komunikatif," 2019, [Online]. Available: https://eproceeding.undwi.ac.id/index.php/inobal i/article/view/197.

[20] Depdiknas, Standar Kompetensi. Jakarta: Depdiknas, 2006.

[21] G. Tarigan and D. Tarigan, Pandai Berbahsa Indonesia, 4th ed. 1992.

[22] M. Sepyanda, "The importance of English subject in elementary school curriculum," importance English Subj. Elem. Sch. Curric., vol. 1, no. 1, pp. 206-216, 2017, [Online]. Available:

http://ejournal.unp.ac.id/index.php/eltar/article/v iew/8722.

[23] J. E. Rini, "English in Indonesia: Its position among other languages in Indonesia," Beyond Words, vol. 2, no. 2, pp. 19-40, 2014, [Online]. Available: https://doi.org/10.33508/bw.v2i2.591.

[24] H. G. Tarigan, Pengajaran kosakata, 2nd ed. Bandung: Angkasa, 1989.

[25] H. Kridalaksana, Kamus Linguistik, 3rd ed. Jakarta: Gramedia Pustaka Utama, 2001.

[26] E. Sarigül, "The importance of using dictionary in language learning and teaching," Selçuk Üniversitesi Edeb. Fakültesi Derg., vol. 13, pp. 153-157, 2016, [Online]. Available: https://dergipark.org.tr/tr/pub/sefad/issue/16474/ 171953.

[27] O. Gonzalez, "Building vocabulary: Dictionary consultation and the ESL student," J. Adolesc. Adult Lit., vol. 43, no. 3, pp. 264-270, 1999, [Online].

Available: https://www.jstor.org/stable/40012150 .

[28] P. Y. Gu, "Vocabulary learning in a second language: Person, task, context and strategies," TESL-EJ, vol. 7, no. 2, pp. 1-25, 2003, [Online].
Available: https://www.teslej.org/wordpress/issues/volume7/ej26/ej26a4/.

[29] C. Miyanaga, “Anxiety, strategies, motivation, and reading proficiency in Japanese university EFL learners," Temple University, 2006.

[30] J. Piaget, "The stages of the intellectual development of the child," Bull. Menninger Clin., vol. 26, no. 3, p. 120, 1962.

[31] N. M. Dhanawaty, "Perlunya pembelajaran bahasa Bali yang rekreatif di sekolah dasar multikultural dan multilingual," Madah, vol. 4, no. 2, pp. 120-130, 2013, [Online]. Available: https://dx.doi.org/10.26499/madah.v4i2.534.

[32] O. Farhrohman, "Implementasi pembelajaran bahasa Indonesia di SD/MI," PRIMARY, vol. 9, no. 1, pp. 23-34, 2017, [Online]. Available: http://jurnal.uinbanten.ac.id/index.php/primary/a rticle/view/412.

[33] Sukardjo and U. Komarudin, Landasan Pendidikan: Konsep dan Aplikasinya, 1st ed. Jakarta: Rajawali Pers., 2012.

[34] I. S. P. Nation, Teaching vocabulary strategies and technique. Boston: Heinle Cengage Learning, 2008.

[35] A. Chaer, Leksikografi \& Leksikografi Indonesia. Jakarta: Rineka Cipta, 2007.

[36] J. Walz, "The dictionary as a secondary source in language learning," French Rev., vol. 64, no. 1, pp. 79-94, 1990, [Online]. Available: https://www.jstor.org/stable/395666. 